\title{
Future prospective of wild edible fruits from Bharsar and Adjoining area in Pauri Garhwal Uttarakhand, India
}

\section{Anand Singh Bisht}

College of Horticulture. VCSG Uttarakhand University of Horticulture and Forestry. Bharsar Pauri Garhwal. Uttarakhand. India 246123. Email: drbishtas@gmail.com.

\begin{abstract}
In view of changing of food habits of local communities of Uttarakhand Himalaya, a study to document the native plant genetic resources of fruit importance and products was conducted. Wild edible fruits were documented through scheduled interviews. With the help of respondents the questionnaires were filled up. After conducting the survey in the Bharsar and Adjoining area of Pauri district, the plant species of fruits importance were identified and a large number of traditional food items were enumerated. The relationship between plant species of food products importance and sustainable livelihood was also discussed.
\end{abstract}

Keywords: Plant genetic resources; Uttarakhand Himalaya; Sustainable livelihood; Wild species.

\section{Introduction}

The Himalaya is the perennial source of attractions, curiosity and challenge to human intellect through the ages. Amongst several assets, the vegetation provides an everlasting and interesting field of investigation. The diversity, copiousness as well as uniqueness of the plant components in various habitats retained sound and aesthetic environment of the Himalaya. However, in the recent past couple of years, excessive exploitation of vegetation, unplanned land use, natural disasters and several developmental
Received

April 10, 2017

Accepted

June 15, 2017

Released June 30, 2017

Open Acess

Full Text Article

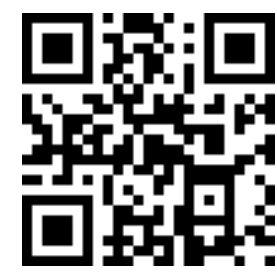

ORCIID

(D) 0000-0002-3471-8585

Anand Singh Bisht processes, accelerated deterioration of vegetation or loss of individual species since we do not possess the detailed botanical record for several of the localities or region. One of such botanical interests and little known region is the Bharsar in district Pauri, which sustain unique and rich genetic resources.

Plant genetic resources continue to play an important role in the development of agriculture, horticulture, forestry etc. World population is expected to increase from 7.0 billion to 9.1 billion by 2050 (WHO, 2012). The world needs astonishing increase in food production to feed this 
population. Plant genetic resources, constitutes the foundation upon which agriculture and world food securities are based and the genetic diversity in the germplasm collection is critical to the world's fights against hunger. They are the raw material for breeding new plant varieties and are a reservoir of genetic diversity.

In view with the multiple stresses and depletion of genetic resources and habitat, today's foremost concern of the globe in general and Himalayas in particular is the conservation of biological diversity, for which detailed description of plant genetic entities are essential. Keeping in view i) the lack of earlier record, ii) diversity and richness of the genetic resources in vast and varied stretch of land, iii) the deterioration of mountain ecosystem, and iv) present day concern of biodiversity, an attempt is made to present the genetic resources with especially wild edible fruits account of the Bharsar region of district Pauri Garhwal, Uttarakhand.

\section{Material and methods}

\section{Study area}

Pauri Garhwal is one of the thirteen districts of Uttarakhand, is located between $29^{\circ} 20^{\prime} \mathrm{N}-29^{\circ} 75^{\prime} \mathrm{N}$ latitude and $78^{\circ} 10^{\prime} \mathrm{E}-$ $78^{\circ} 80^{\prime}$ E longitude, covering about 5,540 $\mathrm{km}^{2}$ area. The district is most fascinating segments of Himalaya, stretches from the Ram Ganga River that separates PauriKumaon border in the East, and to the Ganga demarcating the Western border. Almora, Nainital (East), Chamoli, Tehri and Dehradun (North-West) and adjacent plains of Bijnor, Hardwar (South) districts, surround it. The whole area lies in between Kumaon and Himachal Pradesh Himalaya and considered as a part of North-Western Himalaya.

Bharsar is situated at about $60 \mathrm{~km}$ from the district head quarter (Pauri Garhwal) in the East-South direction on the road side area of Pauri-Thalisain-Ram Nagar National High way 121/41. The Bharsar in is bounded by the temperate evergreen forest towards North-East (Budha Bharsar), North-West (Chauri
Khal), East-South direction occupies terracing crop fields and village namely Dhulet, Sakniyana, Buransi, Nauntha, Sainji etc.

\section{Soil}

The soil texture, colour and nature represent wide range of variations, depending upon geology, altitude, slope aspects, climate, vegetation and biological and chemical interactions. In general, the soil of the Himalaya on the slopes about $30^{\circ}$ represents thin surface horizon. Such skeletal soil has medium to coarse texture, depending the core materials. The valley and gentle slopes have considerable soil depth; developed from colluviums the texture of such soil is generally coarse and least acidic. Decrease in soil $\mathrm{pH}$ with increase of elevation has been reported by some workers, possibly due to leaching out of calcium and magnesium from the surface and simultaneously in much higher altitude of great Himalaya, the trend is reversed. In majority of the places soil is rich in potassium, medium in phosphorous and poor in nitrogen contents, with the exception of some cultigens fields.

\section{Climate}

In general, the climate of the region represents the mild summer, higher precipitation and colder or severe cold prolonged winter. The climate factors i.e. precipitation, temperature, relative humidity and wind, in association with elevation (valleys or mountain range from temperate zone), proximity to Great Himalaya, slope aspects, drainage, vegetation etc are responsible for the micro-climate of this area.

Major output of precipitation is in the form of rain fall, besides occasional occurrence of due, hailstorm, fog, frost, snow fall etc. The South-East monsoon commences towards the end of June while the North-East monsoon causes occasional winter showers during November-February. During winter, snow fall is common in this region. During summer months, the valley has hot climate prevailing for few hours in a day, the maximum temperature during May-June is recorded between 
$30^{\circ} \mathrm{C}-35^{\circ} \mathrm{C}$, however, and nights are cool. December and January are the coldest months, the minimum temperature reaches to $1^{\circ} \mathrm{C}$ to $-4^{\circ} \mathrm{C}$. Relative humidity is normally highest during rainy season (July August), often recorded near to saturation point (92\%-97\%) in thickly forest in this zone, it gradually decreases towards December.

The first half of monsoon start with high velocity winds of South-West to North-West direction, winters have usually northern winds. Thunder storms are of common occurrence during March-May. Impact of winds on the upper zone and steep slopes to influence temperature, precipitation and vegetation are more pronounced. Foggy clouds during rainy season and winter fog in valleys, more or less depend on humidity and wind impacts in the region.

\section{Data colection}

Data on native plant genetic resources of Bharsar and its adjoining area of Uttarakhand were collected from primary sources with the help of planned structured as well as un-structured questionnaire/interview schedule at individual farm household levels during 2014 to 2016. In this regions near about 2035 villages were randomly selected for documentation and interview. During the survey of the study area a non-participant observation method was also applied while recording the information. The wild edible plant species consumed as fruits were documented. The respondent households were also asked to fill up a questionnaire for extracting information on crops under cultivation, wild edible plant species and their recipes. Information obtained was authenticated from knowledgeable elderly people of the villages in the study area. After collection of information on cultivated and wild edible plant species, the information of chemical constitute were also search with different research article was described below under results and discussions.

\section{Results and discussion}

The vegetation is predominantly of forest communities with frequent interruption of scrub jungle and crop field. Several environmental factors control the distribution of vegetation however, usually in the hilly tracts vegetation is demarcated on the basis of altitudinal gradients because edaphic, topographic, climate and associated factors are tend to be altered with altitude.

Apart from the cultivated crop plant species, there are a large number of wild plant species identified by local inhabitants, which provide them fruits round the year (Table 1). Wild edible plant species are not only helpful in supporting the livelihood, but address the economic needs by selling them in the local market.

Table 1. Wild edible plant species used as fruits by local communities.

\begin{tabular}{|l|l|l|l|l|l|}
\hline SN & \multicolumn{1}{|c|}{ Botanical Name } & $\begin{array}{c}\text { Common } \\
\text { name }\end{array}$ & Family & Habit & \multicolumn{1}{c|}{$\begin{array}{c}\text { Chemical } \\
\text { Constitutions }\end{array}$} \\
\hline 1. & Aegle marmelos Linn & Bael & Rutaceae & Tree & $\begin{array}{l}\text { Marmelosin, luvangetin, } \\
\text { psoralen, } \\
\text { aurapten, armelide and tannin } \\
\text { marming } \\
\text { Luvangetin Psoralen } \\
\text { (Maity et al. 2009) }\end{array}$ \\
\hline 2. & $\begin{array}{l}\text { Bauhinia vahlii Wight \& } \\
\text { Arn. }\end{array}$ & Malu & Caesalpiniaceae & Tree & $\begin{array}{l}\text { Agathisflvone, } \\
\text { Stigmasterol, } \\
\text { Isoquercetin, Quercetin, } \\
\text { Betulinic } \\
\text { and }\end{array}$ \\
\hline
\end{tabular}


Table 1. Continued.

\begin{tabular}{|c|c|c|c|c|c|}
\hline SN & Botanical Name & $\begin{array}{c}\text { Common } \\
\text { name }\end{array}$ & Family & Habit & $\begin{array}{c}\text { Chemical } \\
\text { Constitutions }\end{array}$ \\
\hline 3. & Berberis aristata DC. & Chutar & Berberidaceae & Shrub & $\begin{array}{l}\text { Berbamine, Berberine, } \\
\text { oxycanthine, } \\
\text { epiberberine, } \\
\text { palmatine, } \\
\text { dehydrocaroline, } \\
\text { jatrorhizine } \\
\text { columbamine, } \\
\text { karachine (Saied et.al., } \\
\text { 2007). }\end{array}$ \\
\hline 4. & B. asiatica Roxb ex DC. & Kilmora & Berberidaceae & Shrub & $\begin{array}{l}\text { Berbamine, Berberine, } \\
\text { oxycanthine, } \\
\text { epiberberine, } \\
\text { palmatine, } \\
\text { dehydrocaroline, } \\
\text { jatrorhizine } \\
\text { columbamine, } \\
\text { karachine (Saied et al., } \\
\text { 2007). }\end{array}$ \\
\hline 5. & $\begin{array}{l}\text { Callicarpa macrophylla } \\
\text { Vahl. }\end{array}$ & Daya & Verbenaceae & Shrub & $\begin{array}{l}\text { Diterpenoids, } \\
\text { calliterpenone, } \\
\text { sitosterol; luteolin, } \\
\text { apigenin and its 7- } \\
\text { glucuronides; ursolic } \\
\text { acid, its 2-OH } \\
\text { derivetives, crategolic } \\
\text { acid. (Asolkar et al., } \\
\text { 1992). }\end{array}$ \\
\hline 6. & Castanea sativa P. Mill. & $\begin{array}{l}\text { Meetha } \\
\text { pangar }\end{array}$ & Fagaceae & Tree & $\begin{array}{l}\text { Tryptophan, } \\
\text { Threonine, Isoleucine, } \\
\text { Leucune, Lysine, } \\
\text { Methionine, Cystine, } \\
\text { Phenylalanine, } \\
\text { Tyrosine (Barreira et } \\
\text { al., 2012). }\end{array}$ \\
\hline 7. & Celtis australis Linn. & Kharik & Ulmaceae & Tree & $\begin{array}{l}\text { Triterpenoids }(9 \beta \text {, } \\
\text { 31R)-9, 25-cyclo-30- } \\
\text { propylhopan-31-ol, } \\
\text { (3ß)-3-hydroxy- } \\
\text { propylhopan- hydroxy- } \\
\text { trimethoxy, -dioxo- } \\
\text { dihydroanthracen-2-yl } \\
\text { acetate (Badoni et al., } \\
\text { 2011). }\end{array}$ \\
\hline 8. & Citrus medica Linn. & Jamir & Rutaceae & Tree & $\begin{array}{l}\text { Alkaloids, Flavonoids, } \\
\text { Phenols, } \\
\text { Carbohydrates (Negi et } \\
\text { al., 2010) }\end{array}$ \\
\hline 9. & $\begin{array}{l}\text { Corylus jacquemontii } \\
\text { Decne. }\end{array}$ & $\begin{array}{l}\text { Bhotia } \\
\text { badam }\end{array}$ & Betulaceae & Tree & $\begin{array}{l}\text { Gallic acid, catechin, } \\
\text { epicatechin, quercetin, } \\
\text { kaempferol, syringic } \\
\text { acid and p-coumaric } \\
\text { acid (Kumar et al., } \\
\text { 2016). }\end{array}$ \\
\hline
\end{tabular}


Table 1. Continued.

\begin{tabular}{|c|c|c|c|c|c|}
\hline SN & Botanical Name & $\begin{array}{c}\text { Common } \\
\text { name }\end{array}$ & Family & Habit & $\begin{array}{c}\text { Chemical } \\
\text { Constitutions }\end{array}$ \\
\hline 10. & Ficus carica Linn. & Anjir & Moraceae & Tree & $\begin{array}{l}\text { Phytosterols, } \\
\text { anthocyanin } \\
\text { composition, } \\
\text { triterpenoids, } \\
\text { coumarins, } \\
\text { hydrocarbons, (Mawa } \\
\text { et al., 2013). }\end{array}$ \\
\hline 11. & Garuga pinnata Roxb. & Titmar & Burseraceae & Tree & $\begin{array}{l}\text { Alkaloids, } \\
\text { Triterpenoids, Tannins } \\
\text { and } \quad \text { Flavonoids, } \\
\text { Saponins (Harborne, } \\
\text { 1998) }\end{array}$ \\
\hline 12. & $\begin{array}{lll}\text { Grewia optiva } & \text { J.R. } \\
\text { Drumm. ex Burret } & \end{array}$ & Bhimal & Tiliaceae & Tree & $\begin{array}{l}\text { Alkaloids, Tannins, } \\
\text { Anthraquinones, } \\
\text { Glycosides, Terpenoids } \\
\text { (Waliulllah, 2011) }\end{array}$ \\
\hline 13. & $\begin{array}{l}\text { Hippophae tibetana } \\
\text { Schlecht. }\end{array}$ & Turuchuk & Elaeagnaceae & Tree & $\begin{array}{l}\text { Linolenic acid, oleic } \\
\text { acid, palmioleic acid, } \\
\text { palmitic acid, stearic } \\
\text { acid, Vitamin-E and } \beta \text { - } \\
\text { Sitosterol. }\end{array}$ \\
\hline 14. & $\begin{array}{l}\text { Madhuca indica J.F. } \\
\text { Gmel. }\end{array}$ & Mahua & Sapotaceae & Tree & \begin{tabular}{lr}
\multicolumn{2}{l}{ Sapogenin, } \\
triterpenoids, steroids, \\
saponin, & flavonoids \\
and & glycosides, \\
madhucic & acid. \\
Calcium, & Phosphoras, \\
iron, & Carotine, \\
Ascorbic & Acid, \\
Tannins. (Siddiqui et \\
al., 2010)
\end{tabular} \\
\hline 15. & Morus serrata Roxb. & Kimu & Moraceae & Tree & $\begin{array}{ll}\text { Ascorbic } & \text { acid, } \\
\text { riboflavin (vitamin B2) } \\
\text { and niacin (vitamin } \\
\text { B3) }\end{array}$ \\
\hline 16. & $\begin{array}{l}\text { Myrica esculenta Buch.- } \\
\text { Ham. ex D. Don), }\end{array}$ & Kaphal & Myricaceae & Tree & $\begin{array}{l}\text { Myricetin, catechin, } \\
\text { chlorogenic acid and } \rho \\
\text {-coumaric acid } \\
\text { ethanolic 2,2' azinobis } \\
\text { 1,1-diphenyl-2- } \\
\text { picrylhydrazyl (Rawat } \\
\text { et al., 2011) }\end{array}$ \\
\hline 17. & $\begin{array}{l}\text { Phyllanthus emblica } \\
\text { Linn. }\end{array}$ & Aonla & Phyllanthaceae & Tree & $\begin{array}{l}\text { Vitamin C, } \\
\text { Kaempferol-3-O--L-(6- } \\
\text { methyl)- } \\
\text { rhamnopyranoside and } \\
\text { Kaempferol-3-O--L- } \\
\text { (6-ethyl)- } \\
\text { rhamnopyranoside } \\
\text { (Rehman et al., 2007) }\end{array}$ \\
\hline
\end{tabular}


Table 1. Continued.

\begin{tabular}{|c|c|c|c|c|c|}
\hline SN & Botanical Name & $\begin{array}{c}\text { Common } \\
\text { name }\end{array}$ & Family & Habit & $\begin{array}{c}\text { Chemical } \\
\text { Constitutions }\end{array}$ \\
\hline 18. & $\begin{array}{l}\text { Pyracantha crenulata (D. } \\
\text { Don) M. Roem. }\end{array}$ & Ghingaru & Rosaceae & Shrub & $\begin{array}{l}\text { Quercetin, } \beta \text {, Sitosterol, } \\
\beta, \text { Esculetin, heavy } \\
\text { metals, e.g mercury, } \\
\text { lead, lithium } \\
\text { (Bahuguna and } \\
\text { Chakraborthy, 2014) }\end{array}$ \\
\hline 19. & $\begin{array}{l}\text { Pyrus pashia Buch.-Ham. } \\
\text { ex D. Don }\end{array}$ & Mehal & Rosaceae & Tree & $\begin{array}{l}\text { Glycosides, steroids, } \\
\text { triterpenoids, phenols } \\
\text { flavonoids, Saponins, } \\
\text { lupeol (Hemalatha et } \\
\text { al., 2016) }\end{array}$ \\
\hline 20. & Rubus niveus (Hook f.) & $\begin{array}{l}\text { Kala } \\
\text { hisalu }\end{array}$ & Rosaceae & Shrub & $\begin{array}{l}\text { Phenolics, flavonoids, } \\
\text { monomeric } \\
\text { anthocyanins, ascorbic } \\
\text { acid and } \beta \text {-carotene, } \\
\text { Gallic acid, catechin, } \\
\text { chlorogenic acid and } \\
\text { caffeic (Badhani et al., } \\
\text { 2015) }\end{array}$ \\
\hline 21. & Rubus ellipticus Smith & Hisalu & Rosaceae & Shrub & $\begin{array}{l}\text { Phenolics, flavonoids, } \\
\text { monomeric } \\
\text { anthocyanins, ascorbic } \\
\text { acid and } \beta \text {-carotene, } \\
\text { Gallic acid, catechin, } \\
\text { chlorogenic acid and } \\
\text { caffeic (Badhani et al., } \\
\text { 2015) }\end{array}$ \\
\hline 22. & Vitis lanata Roxb. & Purain & Vitaceae & Climbe & $\begin{array}{l}\text { Vitamin C, Protein. } \\
\text { phosphorus, potassium, } \\
\text { calcium, magnesium } \\
\text { and iron (Parmar and } \\
\text { Kaushal, 1982) }\end{array}$ \\
\hline
\end{tabular}

Farming communities and other inhabitants of the Uttarakhand hills had knitted their food and nutritional security web around the available resources, climatic and geographic conditions. The study reveals that there are 22 wild edible plant species are consumed as fruits by the inhabitants. The utilization of a large number of plant species and their products are not observed anywhere else. Apart from food security, nutritional security is also taken into consideration by the inhabitants. Traditional knowledge based subsistence of farming communities is a well instance observed in the Uttarakhand. Growing a large number of crops and their varieties in a mixed cropping pattern is not only a compulsion, but of paramount importance in view of food security. This pattern fulfills the requirement of farm households and helps them to sustain their livelihood in the region. In case of scarcity or unavailability of cultivated food items, they also collect the edible plant species from wild stand. If, production of the some perishable vegetables is available in more than sufficient quantity, they preserve them in the form of khwaire, baries, etc.

The preferred edible species of both cultivated and wild varieties need to be screened for nutritional evaluation (protein, sulfur, amino acids, etc.), and consumer 
acceptance factors (cooking time, taste, texture, and appearance of prepared dishes). Without preference characteristics, the cultivated and the wild edibles will find any market. The preferred varieties if identified for good nutritional value and high consumer acceptance may return good economy to the rural people. The urgent need is to identify and disseminate the valuable information about the important ethnobotanical species and knowledge held with the stakeholders for the benefit of society (Kala, 2007).

Unemployment in Uttarkhand is currently an acute problem. There are not enough public sector jobs for all educated young people. The threat of unemployment could certainly be reduced if educated as well as uneducated and unemployed youths in this region engaged themselves fully in the preparation of quality food and other products from wild edible fruits. It is clear that items prepared from the variety of fruits have promising economic potential. Total output and net return are very high for the food items described, because all these plants grow abundantly in the wild and no further inputs are required, except collecting the fruit (Maikhuri, 2004). The Central Himalaya, particularly Uttarakhand, is an important religious and tourist center, visited by millions of pilgrims and tourists every year. If the quality of fruit products is improved, demand will increase rapidly. If necessary, cooperatives could be started at the village level to carry out marketing responsibilities for edible products prepared from wild plants. Problems such as lack of marketing skill, exploitation by middlemen, and difficulties in obtaining Food Product Order (FPO) permits from government authorities will have to be confronted, however.

If the people of Uttarakhand begin to derive economic benefits from the region's plants, the natural environment will automatically be conserved in situ, and links in the food chain of the ecosystem will be maintained. It is high time to undertake in-depth scientific research on precious, underutilized plant species with huge economic and ecological potential for sustainable development of the traditional societies inhabiting the high mountainous regions of Uttarakhand.

\section{Conflict of interests}

The author declare that there are no conflicts of interest.

\section{References}

Asolkar, L. V.; Kakkar, K. K.; Charke, O. J. Second supplement to glossary of Indian medicinal plants with active principles. Part-I (A-K) (1965-1981). New Delhi, India: Publications and Information Directorate (CSIR), 1992.

Badoni, R.; Semwal, D. K.; Rawat, U.; Rawat, M. S. M. Chemical constituents from fruits and stem bark of Celtis australis L. Helvetica Chemica Acta, v. 94, No. 3, p. 464-473, 2011.

Badhani, A.; Rawat, S.; Bhatt, I. D.; Rawal, R. S. Variation in chamical constituents and antioxidant activity in yellow Himalayan (Rubus ellipticus Smith) and hill raspberry (Rubus niveus Thunb.). Journal of Food Biochemistry, v. 39, No. 6, p. 663-672, 2015. https://dx.doi.org/10.1111/jfbc.12172

Bahuguna, Y. M.; Chakraborthy, G. S. Phytochemical examination of fruits of Pyracantha crenulata (D. Don) M. Roemer. International Journal of Advances in Pharmaceutical Research, v. 5, No. 5, p. 267273, 2014. Available from: <http://www.ijapronline.org/admin/images/2014 0713_Yogendr M. Bahuguna, et al IJAPR.pdf $>$. Accessed on: Feb. 25, 2017.

Barreira, J. C. M.; Casal, S.; Ferreira, I. C. F. R.; Peres, A. M.; Pereira, J. A.; Oliveira, M. B. P. P. Chemical characterization of chestnut cultivars from three consecutive years: chemometrics and contribution for authentication. Food and Chemical Toxicology, v. 50, p. 2310-2317, 2012. https://dx.doi.org/10.1016/j.fct.2012.04.008

Chauhan, R.; Saklani, S. Bahunia vahlii: plant to be explored. Int. J. of Pharmacy, v. 4, No. 8, p. 5-9, 2013.

Harborne, J. B. Phytochemical methods: a guide to modern techniques of plant analysis. London: Chapman and Hall, 1998.

Hemalatha, S.; Sharma, P.; Prasad, S. K. Quality Control standardization of Wild Himalayan Pear: Pyrus pashia. Pharmacognosy Journal, v. 8, No. 4, p. 352360, 2016. 
Kala, C. P. Prioritization of cultivated and wild edibles by local people in the Uttaranchal Hills of Indian Himalaya. Indian Journal of Traditional Knowledge, v. 6, No. 1, p. 239244, 2007.

Kumar, A.; Kumar, P.; Koundal, R.; Agnihotri, V.K. Antioxidant properties and UPLCMS/MS profiling of phenolics in Jacquemont's Hazelnut Kernels (Corylus jacquemontii) and its byproducts from Western Himalaya. J. Food Sci. Tech., v. 53, No. 9, p. 3522-3531, 2016.

Maikhuri, R. K.; Rao, K. S.; Saxena, K. G. Bioprospecting of Wild Edibles for Rural Development in the Central Himalayan Mountains of India. Mountain Research and Development, v. 24, No. 2, p. 110-113, 2004.

Maity, P.; Dhananjay, H.; Uday, B.; Mishra, D. K. Biological activities of crude extracts and chemical constituents of Bael, Aegle marmelos (L.) Corr. Indian Journal of Experimental Biology, v. 47, p. 849-861, 2009.

Mawa, S.; Husain, K.; Ibrahim, J. Ficus carica L. (Moraceae): phytochemistry, traditional uses and biological activities. Evidence-Based Complementary and Alternative Medicine, v. 2013, Article ID 974256, 8 p., 2013. https://dx.doi.org/10.1155/2013/974256

Negi, S. A.; Juyal, V.; Melkani, A. B. Analgesic activity of fruit decoction of Citrus medica Linn. Journal of Pharmacy Research, v. 3, No. 9, p. 2119-2121, 2010.

Parmar, C.; Kaushal, M. K. Wild fruits. New Delhi, India: Kalyani Publishers, 1982.
Rawat, S.; Jugran, A.; Giri, L.; Bhatt, I. D.; Rawal, R. S. Assessment of antioxidant properties in fruits of Myrica esculenta: a popular wild edible species in Indian Himalayan Region. Evidence-Based Complementary and Alternative Medicine, v. 2011, Article ID 512787, 8 p., 2011. https://dx.doi.org/10.1093/ecam/neq055

Habib-un-Rehman; Yasin, K. A.; Choudhary, M. A.; Khaliq, N.; Atta-un-Rahman; Choudhary, M. I.; Malik, S. Studies on the chemical constituents of Phyllanthus emblica. Natural Product Research, v. 21, No. 9, p. 775-781, 2007. https://dx.doi.org/10.1080/14786410601124664

Roberto, C. The MacDonald encyclopedia of medicinal plants. London: MacDonald \& Co. Publication, 1984.

Saied, S.; Batool, S.; Naz, S. Phytochemical studies of Berberis aristata. J. of Basic and Applied Sciences, v. 3, No. 1, p. 1-4, 2007.

Siddiqui, B. S.; Khan, S.; Kardar, M. N. A new isoflavone from the fruits of Madhuca latifolia. Natural Product Research, v. 24, No. 1, p. 7680, 2010. https://dx.doi.org/10.1080/14786410 902830100

WHO. Press Release. 2012. Available from: $<$ http://www.un.org>. Accessed on: Feb. 25, 2017. 